\title{
TIPE KEPRIBADIAN PADA MAHASISWA KELAS MANAJEMEN UNIVERSITAS BINA NUSANTARA DENGAN MENGGUNAKAN MYERS-BRIGGS TYPE INDICATOR (MBTI)
}

\author{
Son Wandrial \\ Management Department, School of Business Management, BINUS University \\ Jln. K. H. Syahdan No. 9, Palmerah, Jakarta Barat 11480 \\ sonwandrial@binus.ac.id; snowalrival@yahoo.com
}

\begin{abstract}
This article was made to identify the personality type of students I teach using the MBTI models. There are 32 standard questions in the questionnaire, and students are asked to choose one of two available answers for each question. Furthermore, students return all questionnaires had been answered, and the researcher calculates and gives the scores to the answers given referring to the four types of the MBTI whether the student is in the category: Extrovert-Introvert, Sensing-Intutive, Thinking-Feeling, and Judging-Perceiving. There are 16 personality types in the MBTI. The question took from the book Richard L Daft. The results show the majority of students is extroversion type in approximately $60.31 \%$, and the rest is introversion type and about $58.78 \%$ of students are sensing type
\end{abstract}

Keyword: MBTI, personality type, decision making

\begin{abstract}
ABSTRAK
Artikel ini dibuat untuk mengidentifikasi tipe kepribadian dari mahasiswa-mahasiswa yang saya ajar dengan menggunakan model MBTI. Terdapat 32 pertanyaan baku dalam kuesioner, dan mahasiswa diminta untuk memilih salah satu dari dua jawaban yang tersedia untuk setiap pertanyaan. Selanjutnya mahasiswa mengembalikan semua kuesioner yang telah dijawab, dan peneliti menghitung dan memberikan nilai skor pada jawaban yang diberikan sesuai dengan empat tipe dari MBTI apakah mahasiswa tersebut masuk dalam kategori: Extrovert-Introvert, Sensing-Intutive, Thinking-Feeling dan Judging-Perceiving. Ada 16 personality types in MBTI. Pertanyaan mengambil dari buku Richard L Daft. Hasil menunjukan mayoritas mahasiswa memiliki tipe Extraversi sekitar 60,31\% selebihnya adalah Introversi dan sekitar58,78\% mahasiswa adalah tipe Sensing
\end{abstract}

Kata kunci: MBTI, tipe kepribadian, pengambilan keputusan 


\section{PENDAHULUAN}

Sifat dan perilaku manusia berbeda-beda, begitupun mahasiswa di kelas dengan beragam perilaku mereka. Ada mahasiswa yang rajin dan selalu tepat waktu masuk kelas, sementara ada mahasiswa selalu terlambat. Ada mahasiswa yang selalu duduk di barisan bangku paling depan, sementara mahasiswa lainnya banyak lebih memilih duduk merapat pada tembok di belakang kelas. Sering dijumpai mahasiswa yang selalu berbicara dengan teman terutama mereka yang duduk di barisan belakang, tapi tidak sedikit juga dari mereka yang memperhatikan dan rajin mencatat saat dosen menerangkan materi perkuliahan di depan kelas. Ada kelas dimana banyak mahamahasiswa yang memiliki nilai diatas rata-rata dan ada juga yang dibawah rata-rata. Sangat beragam sifat dan perilaku mahasiswa yang ditemui di kelas.

Pengalaman peneliti dalam mengajar dua kelas paralel, menunjukan perilaku mahamahasiswa yang berbeda. Contohnya, di satu mata kuliah yang memakai lima text book, ada satu kelas yang hampir semua mahasiswa bisa memiliki empat dari lima buku wajib yang dipakai sesuai silabus, sementara mahasiswa di kelas lain hanya sanggup memiliki dua buku wajib, padahal semua buku tersebut bisa diperoleh di toko buku. Dalam penilaian ujian tengah dan akhir semester, kelas pertama memiliki nilai yang jauh lebih bagus dibanding kelas kedua, begitu juga dalam hal presentasi materi kuliah. Apabila ingin mengubah perilaku seseorang maka harus terlebih dulu mengubah pola pikir orang tersebut. Selama pola pikir belum diubah maka perilaku akan sulit untuk diubah. Perilaku yang beragam dari mahasiswa tersebut terutama perilaku negatif, tentu akan berdampak pada keefektifan pembelajaran di kelas. Kondisi kelas yang tertib, tenang, tidak berisik dan mendapat respon penuh dari mahasiswa adalah kondisi ideal yang diinginkan baik oleh dosen maupun mahasiswa sendiri. Artikel ini mencoba untuk memahami hal apa saja yang melatarbelakangi perilaku dari mahasiswa tersebut dengan menggunakan pendekatan kognitif (cognitive style) yaitu dengan mengidentifikasi tipe kepribadian mahasiswa dengan menggunakan model MBTI. Diharapkan dengan memahami tipe kepribadian mahasiswa, maka dosen bisa merancang bentuk pembelajaran yang sesuai sehingga perilakumahasiswa bisa menjadi lebih baik lagi dan tujuan pembelajaran akan tercapai.

\section{METODE}

Para ahli banyak meneliti tentang perilaku manusia dan menyimpulkan beberapa faktor yang bisa dipakai sebagai penentu dari sifat dan perilaku manusia, antara lain: kepribadian (personality), nilai (value) yang dianut, motivasi dan gaya kognitif (cognitive style). Daft (2005) meyebutkan dua pendekatan cognitive style yaitu Herman Whole Brain Model dan Myers-Brigss Type Indicator (MBTI). Artikel ini menggunakan pendekatan MBTI dengan jenis dan komposisi pertanyaan yang berhubungan dengan MBTI berdasarkan buku Daft tersebut. Kuesioner pertanyaan disebar melalui forum diskusi Binusmaya pada semua mahasiswa di tujuh kelas. Mahasiswa dimohon untuk mengunduh, mencetak dan mengisi kuesioner tersebut.

Terdapat 32 pertanyaan baku dalam kuesioner tersebut dan mahasiswa diminta untuk memilih satu dari dua jawaban yang tersedia untuk setiap pertanyaan. Selanjutnya mahasiswa mengembalikan semua kuesioner yang telah dijawab dan selanjutnya saya menghitung dan memberikan nilai skor pada jawaban yang diberikan sesuai dengan empat bagian dari MBTI apakah mahasiswa tersebut masuk dalam kategori: Extrovert-Introvert, Sensing-Intutive, Thinking-Feeling dan Judging-Perceiving. Panduan penskoran untuk masing-masing jawaban sudah tersedia di buku Daft. Setelah penskoran selesai akan terlihat bentuk kepribadian dari satu orang mahasiswa berdasarkan kombinasi dari keempat bagian dari MBTI seperti: ESTJ (Extrovert Sensing Thinking Judging) atau INTP (Introvert Intuition Thinking Perceiving), terdapat 16 bentuk kombinasi kepribadian. 


\section{Tentang MBTI}

Terdapat banyak alat yang bisa dipakai untuk memahami kepribadian manusia, salah satunya yang dikembangkan oleh Briggs dan Myers (Dalam Wang et.al, 2012) pada masa Perang Dunia II. Ibu dan anak asal Amerika Serikat itu mengembangkan teori kepribadian dari konsep Carl Gustav Jung, psikolog asal Swiss, dan melahirkan Myers Briggs Type Indicator (MBTI). Sejarah MBTI dimulai dengan Carl Jung, pendiri psikologi analitis. Jung percaya bahwa orang-orang mendapatkan energi dari dunia luar (Extraversion) atau dunia internal mereka sendiri (Introversion). Dia juga mengamati bahwa orang mengambil informasi (Perceiving) atau mengorganisir informasi dan memunculkan kesimpulan (Judging).

Walaupun pada awalnya indikator ini digunakan untuk dunia kerja, namun dalam perkembangannya ukuran ini bisa dipakai pada berbagai aspek kehidupan seperti tempat kerja, sekolah, komunitas sosial dll. Ada 16 tipe kepribadian MBTI, yang menjadi petunjuk kepribadian seseorang, tentu setelah sebelumnya melalui suatu tes.

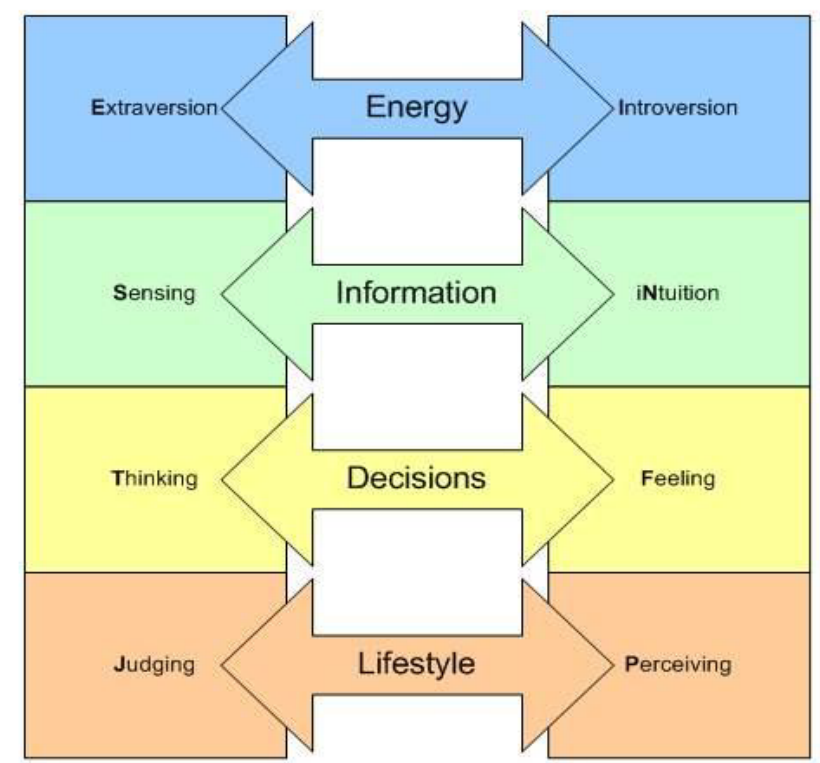

Gambar 1 Pengelompokan MBTI 
Tabel 1 MBTI Penjelasan Skala Preferensi

\begin{tabular}{ll}
\hline Scale & Descriptions \\
\hline E/I - Energy Sources - & Extraversion (E), mengacu pada \\
Extraversion/Introversion & tindakan atau keadaan dimana energi \\
& seseorang diperoleh dari dunia luar. \\
& Extravert menikmati bersosialisasi dan \\
& cenderung lebih antusias, tegas, aktif \\
& berbicara. Mereka menikmati waktu \\
& yang dihabiskan dengan lebih banyak \\
& orang dan merasa kurang nyaman \\
& untuk menghabiskan waktu sendirian.
\end{tabular}

S/N - Perceiving Mental Function: "Data Gathering" (What do you first notice?)

T/F - Judging Mental Function: "Decision Making" (How do you prefer to make decisions?)

Scale Descriptions $\mathbf{J} / \mathbf{P}$ - Orientation (How people express perceptions or judgments in the outer world)
Sensing (S), mengacu pada pengolahan data melalui panca indera. Orang tipe sensing fokus pada masa sekarang dan lebih memilih untuk learn by doing. Mereka adalah pemikir konkret yang mengetahui detail. Mereka lebih bersemangat dengan penggunaan praktis dari sebuah objek / ide daripada teori di belakangnya.

Thinking (T), mengacu pada bagaimana orang membuat keputusan. Orang tipe Thinking merupakan orang yang objektif dan mendasarkan keputusan mereka pada logika dan fakta nyata. Mereka cenderung untuk menganalisis pro dan kontra dari situasi dan inkonsistensi. Mereka lebih memilih untuk menjadi berorientasi pada tugas.

Judging (J), mengacu pada bagaimana orang secara lahiriah menampilkan diri mereka ketika membuat keputusan. Orang tipe ini memiliki kecenderungan untuk terorganisir dan cepat. Mereka suka memilih urutan jadwal yang digariskan untuk bekerja. Mereka lebih berorientasi pada hasil akhir dibanding proses.
Introversion (I), sebaliknya, adalah keadaan yang dido-minasi lebih peduli dengan dunia dalam seseorang. Introvert lebih suka refleksi diri daripada interaksi sosial. Mereka juga lebih memilih untuk mengamati sebelum berpartisipasi dalam suatu kegiatan. Introvert cenderung lebih tenang, damai, dan pendiam. Catatan: Introvert lebih suka aktivitas individu di atas kegiatan

kemasyarakatan, jangan keliru dengan orang-orang pemalu yang takut akan situasi sosial

Intuisi (I), mengacu pada bagaimana individu mem-proses data. Orang tipe intuitif lebih tajam untuk arti dan pola di balik informasi. Orang tipe intuitif lebih terfokus pada bagaimana saat ini akan mem-pengaruhi masa depan. Mereka sudah mampu memahami kemungkinan yang berbeda dan konsep abstrak. Mereka dengan mudah melihat gambaran be-sar daripada rincian

Feeling (F), Orang perasa adalah orang lebih subjektif. Mereka mendasarkan keputusan mereka pada prinsip-prinsip dan nilai-nilai pribadi. Ketika membuat keputusan, me-reka mempertimbangkan perasaan orang lain. Hal ini adalah yang terbaik untuk memelihara kerukunan an-tar kelompok. Mereka lebih diatur oleh hati mereka

Perceiving (P), adalah orang lebih suka fleksibilitas dan menjalani hidup mereka dengan spontanitas. Mereka tidak menyukai struktur dan lebih memilih untuk beradaptasi dengan situasi baru daripada merencanakan untuk itu. Mereka cenderung terbuka untuk pilihan baru dan penga-laman. Ketika bekerja pada sebuah proyek, mereka menikmati proses dari pada hasil

Terdapat 16 tipe kepribadian dalam MBTI. Masing-masing tipe kepribadian tersebut merupakan perpaduan dari empat huruf, yang memiliki arti tersendiri. Klasifikasi kepribadian menunjukkan dinamika dan sistem hubungan yang kompleks dari kepribadian. Huruf pertama dan keempat menunjukkan sikap atau orientasi, karena mereka harus melakukan dengan cara seseorang berinteraksi dengan dunia. Huruf kedua dan ketiga menunjukkan fungsi mental, karena hal itu merupakan dasar dari cara kerja otak. Dua huruf yang ada di tengah ini dinamakan fungsi yang yang berpasangan. 
Tipe kepribadian individu dinyatakan sebagai salah satu dari enam belas kemungkinan kombinasi preferensi ini. Sebagai contoh, seorang ENTP akan memiliki preferensi untuk extraversion, intuisi, pemikiran, dan persepsi. Penjelasan dari masing-masing tipe kepribadian bisa dilihat pada tabel dibawah ini.

Tabel 216 Tipe Kepribadian MBTI

\begin{tabular}{|c|c|c|c|c|}
\hline & \multicolumn{2}{|c|}{ Sensing Types } & \multicolumn{2}{|c|}{ Intuitive Types } \\
\hline & $\begin{array}{l}\text { ISTJ } \\
\text { Tipe Realis Tepercaya rendah hati } \\
\text { dan sangat memikirkan tanggung } \\
\text { jawab. Mereka cermat, pendiam, } \\
\text { dan menuntut. Sifat mereka yang } \\
\text { paling menonjol adalah dapat } \\
\text { diandalkan dan mereka akan selalu } \\
\text { berusaha memenuhi janji yang } \\
\text { pernah mereka lon-tarkan. } \\
\text { Tipe Realis Terper-caya adalah } \\
\text { orang-orang yang cenderung tidak } \\
\text { banyak bicara dan serius, mereka } \\
\text { tidak banyak bicara namun } \\
\text { pendengar yang baik. Pendiam, } \\
\text { serius, menggunakan fakta, } \\
\text { realistis dan bertanggung jawab. } \\
\text { Memutuskan secara logis dan } \\
\text { konsisten. Senang dengan ke- } \\
\text { teraturan. Memegang kuat nilai } \\
\text { tradisi dan loyalitas. }\end{array}$ & $\begin{array}{l}\text { ISFJ } \\
\text { Tipe Realis Baik Hati adalah } \\
\text { pribadi-pribadi yang hangat dan } \\
\text { suka menolong. Mereka me- } \\
\text { lakukan pekerjaan me-reka } \\
\text { dengan sungguh-sungguh dan } \\
\text { memiliki bakat mengorganisir } \\
\text { yang menonjol. Kepua-san } \\
\text { tertinggi mereka adalah ketika } \\
\text { menja-dikan diri mereka ber-guna } \\
\text { dan mengurus orang lain. } \\
\text { Namun mereka tidak suka } \\
\text { menonjolkan diri; mereka lebih } \\
\text { suka me-nuntaskan pekerjaan } \\
\text { mereka di luar sorotan. Mereka } \\
\text { adalah pecandu kerja yang } \\
\text { sesung-guhnya } \\
\text { Pendiam, ramah, ber- } \\
\text { tanggungjawab dan te-liti. Peduli } \\
\text { dengan pe-rasaan orang lain. Be- } \\
\text { rusaha keras membuat } \\
\text { keharmonisan di lingku-ngan } \\
\text { rumah dan peker-jaannya. }\end{array}$ & $\begin{array}{l}\text { INFJ } \\
\text { Tipe Idealis Penyelaras dikenali } \\
\text { dari kepriba-diannya yang kom- } \\
\text { pleks dan memiliki begitu banyak } \\
\text { pemi-kiran dan perasaan. Mereka } \\
\text { orang yang pada dasarnya bersifat } \\
\text { hangat dan penuh pe-ngertian. } \\
\text { Memiliki keinginan un-tuk } \\
\text { mengerti hal-hal yang memotivasi } \\
\text { dan menginspirasi orang. Mereka } \\
\text { memiliki pe-mahaman yang kuat } \\
\text { tentang sifat-sifat ma-nusia. Teliti } \\
\text { dan komit pada nilai-nilai dimana } \\
\text { dia berada. Teratur dan tegas } \\
\text { dalam me-wujudkan cita-citanya. } \\
\text { Tipe ini menganggap konflik } \\
\text { sebagai situasi yang tidak menye- } \\
\text { nangkan dan lebih menyukai } \\
\text { hubungan harmonis. }\end{array}$ & $\begin{array}{l}\text { INTJ } \\
\text { Tipe Pemikir Mandiri adalah } \\
\text { orang-orang yang analitis dan } \\
\text { jenaka. Mereka biasanya } \\
\text { percaya diri dan tidak } \\
\text { membiarkan diri terganggu } \\
\text { oleh konflik dan kritik. Mereka } \\
\text { sangat sadar akan kekuatan } \\
\text { mereka sendiri dan tidak ragu } \\
\text { akan kemampuan mereka. } \\
\text { Orang bertipe kepri-badian ini } \\
\text { biasanya sangat sukses dalam } \\
\text { karir karena mereka memiliki } \\
\text { baik kompetensi maupun tekad. } \\
\text { Tipe ini tidak tahan dengan } \\
\text { rutinitas. } \\
\text { Memiliki pikiran yang original. } \\
\text { Bila berkomitmen, dia akan } \\
\text { melaksanakan pekerjaan } \\
\text { dengan baik. }\end{array}$ \\
\hline & $\begin{array}{l}\text { ISTP } \\
\text { Tipe Pelaku Individu-alistis adalah } \\
\text { orang-orang yang yakin akan diri } \\
\text { sendiri dan sangat mandiri. } \\
\text { Mereka orang-orang yang pendiam } \\
\text { dan realistis, sangat rasional, dan } \\
\text { sangat tegas. Mereka memelihara } \\
\text { individualisme mereka dan senang } \\
\text { mene-rapkan kemampuan mereka } \\
\text { pada tugas-tugas baru. } \\
\text { Mereka tidak terlalu menyukai } \\
\text { kewajiban; namun jika Anda } \\
\text { memberi mereka ru-ang, mereka } \\
\text { adalah orang-orang yang se- } \\
\text { sungguhnya tidak rumit, mudah } \\
\text { bergaul, dan periang. } \\
\text { Toleran dan fleksibel, cenderung } \\
\text { menjadi pengamat sampai muncul } \\
\text { persoalan, ke-mudian bertindak ce- } \\
\text { pat untuk mencari solusi }\end{array}$ & $\begin{array}{l}\text { ISFP } \\
\text { Tipe Pelaku Peka adalah orang- } \\
\text { orang yang lem-but, rendah hati, } \\
\text { dan pendiam. Mereka me-nangani } \\
\text { kehidupan se-hari-hari dengan } \\
\text { baik dan menyukai kele-luasaan } \\
\text { pribadi mereka. Dengan sifat } \\
\text { optimis dan tidak banyak bicara, } \\
\text { mereka juga adalah pendengar } \\
\text { yang baik yang sering dicari } \\
\text { orang dan orang lain merasa } \\
\text { nyaman ditemani mereka. } \\
\text { Tipe ini adalah yang paling } \\
\text { mudah disukai dan paling ramah } \\
\text { di antara semua tipe kepribadian. } \\
\text { Pendiam, bersahabat, sensitif dan } \\
\text { baik. Me-nikmati keadaan saat ini } \\
\text { dan apa yang terjadi pada } \\
\text { lingkungannya. Membenci } \\
\text { perselisihan dan konflik, tidak } \\
\text { me-maksakan opini dan nilainya } \\
\text { pada orang lain }\end{array}$ & $\begin{array}{l}\text { INFP } \\
\text { Tipe Idealis Pemimpi sangat } \\
\text { berhati-hati dan oleh karenanya } \\
\text { tampak pemalu dan pendiam bagi } \\
\text { orang lain. Mereka berbagi } \\
\text { kehidupan emosional mereka } \\
\text { yang kaya serta pendapat kuat } \\
\text { mereka dengan sedikit sekali } \\
\text { orang. Namun orang sering keliru } \\
\text { menilai mereka dingin dan } \\
\text { pendiam. Di tempat kerja, tipe ini } \\
\text { adalah teman dan pasangan yang } \\
\text { suka menolong dan setia } \\
\text { Idealis, loyal, mudah beradaptasi, } \\
\text { fleksibel, dan mudah menerima } \\
\text { kecuali nilai-nilai yang } \\
\text { bertentangan. Ingin tahu, cepat } \\
\text { melihat kemungkinan, bisa } \\
\text { menjadi katalis untuk } \\
\text { menjalankan cita-citanya }\end{array}$ & $\begin{array}{l}\text { INTP } \\
\text { Tipe Pemikir Analitis adalah } \\
\text { orang-orang pendiam dan tidak } \\
\text { banyak bicara. Me-reka suka } \\
\text { menggali hingga ke dasar } \\
\text { masalah, rasa ingin tahu adalah } \\
\text { doro-ngan terbesar me-reka. } \\
\text { Mereka ingin tahu apa yang } \\
\text { me-nyatukan dunia jauh di } \\
\text { dalamnya. Mere-ka tidak butuh } \\
\text { lebih banyak untuk keba- } \\
\text { hagiaan mereka ka-rena mereka } \\
\text { adalah orang-orang yang } \\
\text { rendah hati. } \\
\text { Logis. Secara teori dan abstrak, } \\
\text { tertarik banyak pada ide } \\
\text { daripada interaksi sosial. } \\
\text { Pendiam, fleksibel dan mudah } \\
\text { beradaptasi. Ragu, kadang } \\
\text { kritis dan selalu analitis }\end{array}$ \\
\hline & $\begin{array}{l}\text { ESTP } \\
\text { Tipe Pelaku Berse-mangat adalah } \\
\text { orang-orang periang dan spontan. } \\
\text { Mereka pe-nuh pesona, dipenuhi } \\
\text { energi, dan pelaku-pelaku } \\
\text { sesungguhnya. Mereka memiliki } \\
\text { pe-mikiran dan panda-ngan yang } \\
\text { jernih se-kalipun sedang berada }\end{array}$ & $\begin{array}{l}\text { ESFP } \\
\text { Tipe Pelaku Santai adalah orang- } \\
\text { orang yang ramah dan bahagia. } \\
\text { Mereka menikmati kebersamaan } \\
\text { dengan orang lain. Cerdas, pandai } \\
\text { bicara, jenaka dan penuh pesona, } \\
\text { mereka suka menjadi pusat } \\
\text { perhatian. Mereka tidak takut }\end{array}$ & $\begin{array}{l}\text { ENFP } \\
\text { Tipe Idealis Spontan adalah } \\
\text { orang-orang yang kreatif, periang, } \\
\text { dan berpikiran terbuka. Mereka } \\
\text { penuh humor dan menularkan } \\
\text { sema-ngat menikmati hidup. Tipe } \\
\text { kepribadian ini adalah pengamat } \\
\text { yang tajam dan awas; mereka }\end{array}$ & $\begin{array}{l}\text { ENTP } \\
\text { Tipe Pemikir Pen-dobrak } \\
\text { adalah orang penuh pesona dan } \\
\text { antusias. Mereka benar-benar } \\
\text { penuh dengan energi dan suka } \\
\text { mengambil posisi di tengah- } \\
\text { tengah perhatian. Mereka } \\
\text { menyukai keragaman baik da- }\end{array}$ \\
\hline
\end{tabular}




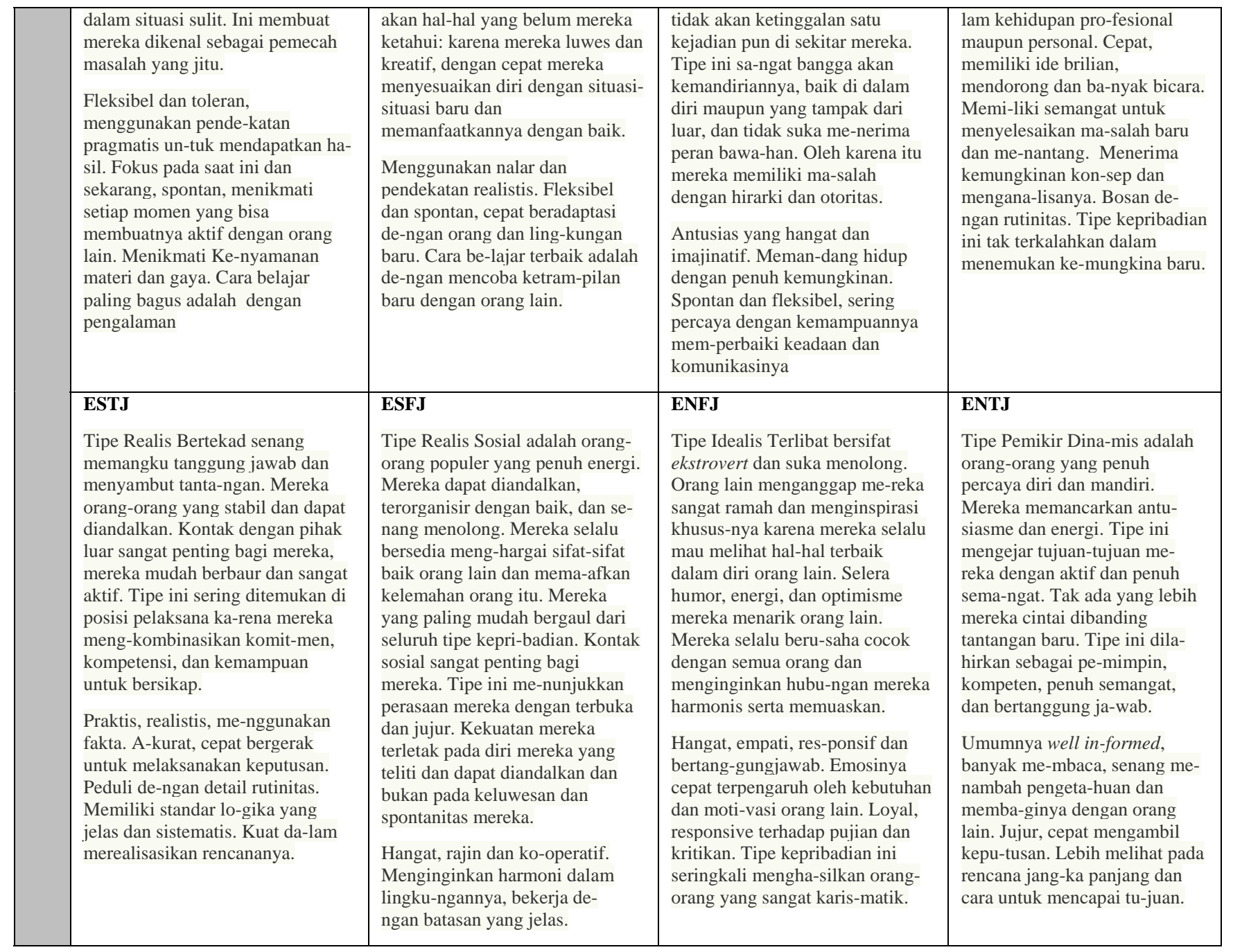

\section{HASIL DAN PEMBAHASAN}

Penyebaran kuesioner melalui forum diskusi dan dari sekitar 415 orang mahasiswa hanya 262 orang yang mengembalikan kuesioner terdiri dari 127 orang mahasiswa pria dan 135 orang wanita, hasilnya terlihat pada tabel dibawah ini.

Tabel 3 Penilaian Kuesioner Extrovert - Introvert

\begin{tabular}{lcc}
\hline & Pria & Wanita \\
\hline Extrovert & 77 & 82 \\
\hline Introvert & 50 & 53 \\
\hline
\end{tabular}


Berdasarkan jenis kelamin, mahasiswa wanita lebih banyak yang memiliki kepribadian Extrovert dibandingkan dengan mahasiswa pria. Begitu juga untuk Introvert, mahasiswa wanita sedikit lebih banyak dibandingkan dengan mahasiswa pria. Karena lebih banyak Extrovert, Ini menunjukan bahwa, kondisi di kelas lebih didominasi oleh mahasiswa dengan perilaku yang senang bersosialisasi, aktif berbicara dan senang berkumpul dengan orang banyak. Bila melihat kondisi ini bisa dipastikan suasana kelas akan seperti apa bila dipenuhi oleh mahasiswa pria dan wanita yang Extrovert, kelas akan lebih berisik.

Tabel 4 Penilaian Kuesioner Thinking - Feeling

\begin{tabular}{lcc}
\hline & Pria & Wanita \\
\hline Thinking & 50 & 38 \\
\hline Feeling & 77 & 97 \\
\hline
\end{tabular}

Termuan yang unik adalah pada pengambilan keputusan (decision making), ternyata banyak mahasiswa pria yang lebih mengandalkan perasaan dalam pengambilan keputusan ketibang logika (thinking), hal ini seperti kecenderungan seorang wanita. Fakta menyebutkan bahwa pria 80\% didominasi oleh otak kiri (logika) dan wanita $80 \%$ oleh otak kanan (perasaan). Semestinya pria lebih mengandalkan logika (thinking) dalam pengambilan keputusa tapi dari hasil penelitian ini menunjukan di kelas lebih banyak pria yang menggunakan perasaan sebelum memutuskan sesuatu, artinya mereka lebih mempertimbangkan perasaan orang lain, subjektif dan berusaha menjaga kerukunan. Sementara untuk mahasiswa wanita menujukan kondisi ideal, dimana penggunaan Thinking mereka lebih rendah daripada pria dan Feeling mereka lebih tinggi daripada pria.

Tabel 5 Hasil Perhitungan MBTI Mahasiswa Kelas Manajemen Binus

\begin{tabular}{|c|c|c|c|c|c|}
\hline & \multicolumn{2}{|c|}{ Sensing Types } & \multicolumn{2}{|c|}{ Intuitive Types } & \\
\hline \multirow{2}{*}{ 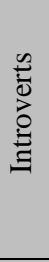 } & $\begin{array}{l}\text { ISTJ } \\
21 \text { mahasiswa } \\
8.02 \%\end{array}$ & $\begin{array}{l}\text { ISFJ } \\
23 \text { mahasiswa } \\
8.78 \%\end{array}$ & $\begin{array}{l}\text { INFJ } \\
11 \text { mahasiswa } \\
4.20 \%\end{array}$ & $\begin{array}{l}\text { INTJ } \\
12 \text { mahasiswa } \\
4.58 \%\end{array}$ & \multirow[b]{2}{*}{$\begin{array}{l}104 \\
\text { mahasiswa } \\
39.69 \%\end{array}$} \\
\hline & $\begin{array}{l}\text { ISTP } \\
4 \text { mahasiswa } \\
1.53 \%\end{array}$ & $\begin{array}{l}\text { ISFP } \\
20 \text { mahasiswa } \\
7.63 \%\end{array}$ & $\begin{array}{l}\text { INFP } \\
10 \text { mahasiswa } \\
3.82 \%\end{array}$ & $\begin{array}{l}\text { INTP } \\
3 \text { mahasiswa } \\
1.15 \%\end{array}$ & \\
\hline \multirow{3}{*}{ 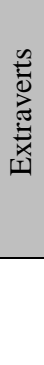 } & $\begin{array}{l}\text { ESTP } \\
9 \text { mahasiswa } \\
3.44 \%\end{array}$ & $\begin{array}{l}\text { ESFP } \\
16 \text { mahasiswa } \\
6.11 \%\end{array}$ & $\begin{array}{l}\text { ENFP } \\
13 \text { mahasiswa } \\
4.96 \%\end{array}$ & $\begin{array}{l}\text { ENTP } \\
7 \text { mahasiswa } \\
2.67 \%\end{array}$ & \multirow[b]{2}{*}{$\begin{array}{l}158 \\
\text { mahasiswa } \\
60.31 \%\end{array}$} \\
\hline & $\begin{array}{l}\text { ESTJ } \\
24 \text { mahasiswa } \\
9.16 \%\end{array}$ & $\begin{array}{l}\text { ESFJ } \\
37 \text { mahasiswa } \\
14.12 \%\end{array}$ & $\begin{array}{l}\text { ENFJ } \\
43 \text { mahasiswa } \\
16.41 \%\end{array}$ & $\begin{array}{l}\text { ENTJ } \\
9 \text { mahasiswa } \\
3.44 \% \\
\end{array}$ & \\
\hline & \multicolumn{2}{|c|}{$\begin{array}{c}154 \text { mahasiswa } \\
58.78 \%\end{array}$} & \multicolumn{2}{|c|}{$\begin{array}{c}108 \text { mahasiswa } \\
41.22 \%\end{array}$} & \\
\hline
\end{tabular}


Dari hasil diatas dapat dilihat sebaran 16 tipe kepribadian MBTI, di mana mayoritas mahasiswa adalah Extrovert sekitar 60,31\% ini berarti mereka adalah mahasiswa-mahasiswa yang senang bekerja dalam suatu aktifitas yang berhubungan dengan orang banyak dan kerja kelompok. Mahasiswa dengan tipe Sensing juga mayoritas yaitu 154 orang atau 58,78\% ini artinya mereka adalah mahasiswa-mahasiswa yang senang dengan pengalaman belajar yang lengkap dan harapan yang jelas, mereka tidak menyukai instruksi berat dalam abstraksi seperti teori dan model matematika. Sementara Intuitors menyukai instruksi yang menekankan pemahaman konseptual.

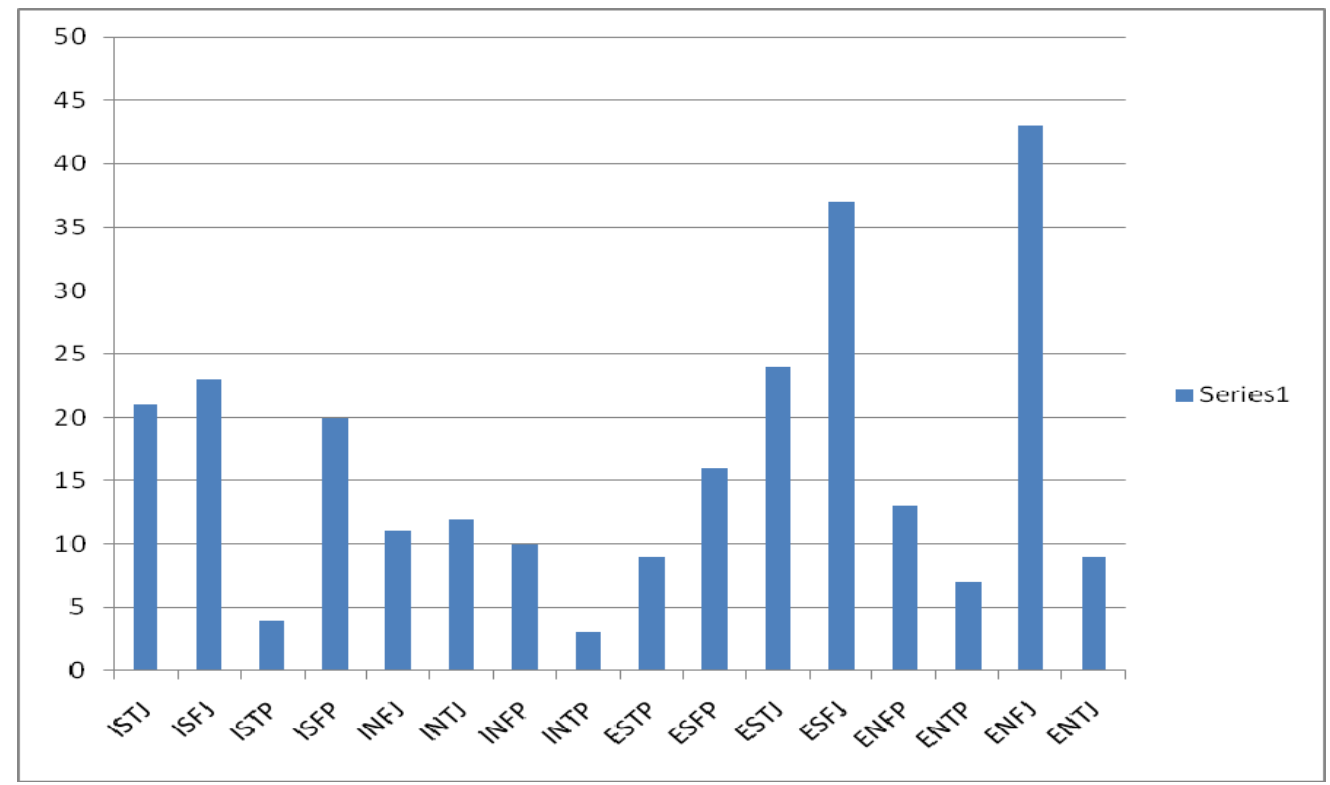

Gambar 2 Grafik Hasil Tes MBTI Mahasiswa Kelas Manajemen Binus

Secara grafik dapat dilihat, mayoritas kepribadian mahasiswa adalah ENFJ (Extrovert Intuition Feeling Judging) sekitar 43 mahasiswa atau 16,41\% dari total mahasiswa yang disurvei. Penjelasan tentang tipe kepribadian ini bisa dilihat pada tabel 2.

\section{SIMPULAN}

Tujuan melaksanakan MBTI adalah untuk mengenali kekuatan dan kelemahan individu serta orang lain. MBTI diciptakan untuk memfasilitasi pemahaman dan apresiasi terhadap perbedaan di antara manusia. Tidak ada jenis perilaku yang lebih baik dibanding yang lain. Dalam penerapan pada manajemen kelas, MBTI sangat berguna untuk memahami tipe kepribadian para mahasiswa dan kita bisa merancang suatu model perkuliahan atau suasana kelas yang bisa menciptakan kondisi kelas yang lebih tertib dan teratur. Sebaiknya tes MBTI ini dilakukan diawal semester perkuliahan sehingga dosen bisa memahami jenis-jenis kepribadian dari mahasiswa yang mereka ajar dan dosen bisa merancang metode perkuliahan yang lebih efektif. 


\section{DAFTAR PUSTAKA}

Admin. (2010). Tes Kepribadian MBTI. Artikel Psikologi, Diakses dari http://afbluesea89.wordpress.com/2010/11/01/tes-kepribadian-mbti/

Daft, R. L. (2005). The Leadership Experience. Thomson South Western.

Felder, R. M., Felder, G.N., Dietz, E. J. (2006). The Effects Of Personality Type On Engineering Student. Performance And Attitude.

Handayani, S. (2013) Kompromi Kepribadian dalam Pernikahan. Ummi Online, Diakses dari http://www.ummi-online.com/berita-915-kompromi-kepribadian-dalampernikahan.html\#.UoMG3z9AdiQ.facebook

Wang, C., Carney, S., Parawan, J. (2012). Myers-Briggs Type Indicator Manual. Wc Personality Inc. 
For each item below, circle either "a" or "b." In some cases, both "a" and "b" may apply to you. You should decide which is more like you, even if it is only slightly more true.

1. I would rather

a. Solve a new and complicated problem

b. Work on something that I have done before

2. I like to
a. Work alone in a quiet place
b. Be where "the action" is

3. I want a boss who

a. Establishes and applies criteria in decisions

b. Considers individual needs and makes exceptions

4. When I work on a project, I

a. Like to finish it and get some closure

b. Often leave it open for possible change

5. When making a decision, the most important considerations are

a. Rational thoughts, ideas, and data

b. People's feelings and values

6. On a project, I tend to

a. Think it over and over before deciding how to proceed

b. Start working on it right away, thinking about it as I go along

7. When working on a project, I prefer to

a. Maintain as much control as possible

b. Explore various options

8. In my work, I prefer to

a. Work on several projects at a time, and learn as much as possible about each one

b. Have one project that is challenging and keeps me busy

9. I often

a. Make lists and plans whenever I start something and may hate to seriously alter my plans

b. Avoid plans and just let things progress as I work on them

10. When discussing a problem with colleagues, it is easy for me
a. To see "the big picture"
b. To grasp the specifics of the situation

11. When the phone rings in my office or at home, I usually
a. Consider it an interruption
b. Don't mind answering it

12. The word that describes me better is
a. Analytical
b. Empathetic

13. When I am working on an assignment, I tend to

a. Work steadily and consistently

b. Work in bursts of energy with "down time" in between

14. When I listen to someone talk on a subject, I usually try to

a. Relate it to my own experience and see if it fits

b. Assess and analyze the message

15. When I come up with new ideas, I generally
a. "Go for it"
b. Like to contemplate the ideas some more

16. When working on a project, I prefer to
a. Narrow the scope so it is clearly defined
b. Broaden the scope to include related aspects

17. When I read something, I usually
a. Confine my thoughts to what is written there
b. Read between the lines and relate the words to other ideas

18. When I have to make a decision in a hurry, I often
a. Feel uncomfortable and wish I had more information
b. Am able to do so with available data

19. In a meeting, I tend to
a. Continue formulating my ideas as I talk about them
b. Only speak out after I have carefully thought the issue through

20. In work, I prefer spending a great deal of time on issues of
a. Ideas
b. People

21. In meetings, I am most often annoyed with people who

a. Come up with many sketchy ideas

b. Lengthen the meeting with many practical details

22. I tend to be
a. A morning person
b. A night owl

23. My style in preparing for a meeting is
a. To be willing to go in and be responsive
b. To be fully prepared and sketch out an outline of the meeting


24. In meetings, I would prefer for people to
a. Display a fuller range of emotions
b. Be more task-oriented

25. I would rather work for an organization where
a. My job was intellectually stimulating
b. I was committed to its goals and mission

26. On weekends, I tend to
a. Plan what I will do
b. Just see what happens and decide as I go along

27. I am more
a. Outgoing
b. Contemplative

28. I would rather work for a boss who is
a. Full of new ideas
b. Practical

In the following, choose the word in each pair that appeals to you more:

29. a. Social

b. Theoretical

30. a. Ingenuity

b. Practicality

31. a. Organized

b. Adaptable

32. a. Activity

b. Concentration

\section{Scoring}

$\begin{array}{llll}2 a & 2 b & 1 b & 1 a \\ 6 a & 6 b & 10 b & 10 a \\ 11 a & 11 b & 13 a & 13 b \\ 15 b & 15 a & 16 a & 16 b \\ 19 b & 19 a & 17 a & 17 b \\ 22 a & 22 b & 21 a & 21 b \\ 27 b & 27 a & 28 b & 28 a \\ 32 b & 32 a & 30 b & 30 a\end{array}$

$\begin{array}{llll}3 a & 3 b & 4 a & 4 b \\ 5 a & 5 b & 7 a & 7 b \\ 12 a & 12 b & 8 b & 8 a \\ 14 b & 14 a & 9 a & 9 b \\ 20 a & 20 b & 18 b & 18 a \\ 24 b & 24 a & 23 b & 23 a \\ 25 a & 25 b & 26 a & 26 b \\ 29 b & 29 a & 31 a & 31 b\end{array}$

Gambar 3 Daftar Pertanyaan tes MBTI 